\title{
The Situation and Challenges of Pineapple Industry in China
}

\author{
Haiyan Shu, Wei Sun, Keming Li, Guiying Xu, Rulin Zhan*, Shenghe Chang* \\ Haikou Experimental Station, Chinese Academy of Tropical Agricultural Sciences, Haikou, China \\ Email: *plantfood772@hotmail.com
}

How to cite this paper: Shu, H.Y., Sun, W., Li, K.M., Xu, G.Y., Zhan, R.L. and Chang, S.H. (2019) The Situation and Challenges of Pineapple Industry in China. Agricultural Sciences, 10, 683-688. https://doi.org/10.4236/as.2019.105053

Received: April 17, 2019

Accepted: May 24, 2019

Published: May 27, 2019

Copyright $\odot 2019$ by author(s) and Scientific Research Publishing Inc. This work is licensed under the Creative Commons Attribution-NonCommercial International License (CC BY-NC 4.0).

http://creativecommons.org/licenses/by-nc/4.0/

\begin{abstract}
Pineapple is the third largest tropical fruit in China. Pineapple industry played important roles in developing economies in tropical- and subtropical-areas in China. However, the structure of varieties is simple. The harvesting period is centralized. The price of pineapple fruits is often low. These challenges hindered the further development of pineapple industry. The people engaged in pineapple industry should select and cultivate new varieties with higher qualities and that can be harvested in a longer period. More work should be done in the technology on inducing inflorescence of new varieties. Precision fertilization for new varieties should be researched and developed. The technology for cultivating tissue-culture seedlings fast and at low cost should also be studied. The diseases in fruits should be prevented and controlled before harvesting.
\end{abstract}

\section{Keywords}

Pineapple, Situation, Challenge, Variety, Disease

\section{Introduction}

Pineapple is the most important economic plant in Bromeliaceae [1]. There are 56 genus and 2600 species in Bromeliaceae. Most of them grow in Central America, northern Argentina and Chile. It is the third largest tropical fruit in the world, only less than banana and mango [2]. Pineapple originated in the area between latitude 40 degrees north and latitude 40 degrees south, 55 degrees west of Greenwich and 75 degrees west of Greenwich. Columbus found pineapple in Guadeloupe in 1493. At that time, pineapples have been grown in Central America widely. Several local varieties have been domesticated. In the $16^{\text {th }}$ century, pineapple was introduced into Europe. In the $18^{\text {th }}$ century, pineapple was 
introduced into Asia and Africa.

There are 1,000,000 hectares of pineapple in the world. Most of them are distributed in Asia and Africa. There are 400,000 hectares of pineapple in Asia. About 70,000 hectares are distributed in China. Pineapple is mostly grown in Guangdong, Hainan, Yunnan, Guangxi, Fujian, Taiwan in China [3]. Eighty four percent of pineapple was grown in Guangdong and Hainan [3]. The main cultivar of pineapple in China is "Comte de Paris" introduced from Philippines, accounting for more than $80 \%$ of the total pineapple production [2].

Most of pineapples in China are sold in fresh fruit [3]. In the recent 15 years, trade of fresh fruit of pineapple increased by $14 \%$ every year. Pineapple tin is one of the best fruit tins in the world. There are 1,000,000 tons of pineapple tins in the trade among different countries every year. Pineapple fruit is also produced into fruit juice and tin. Bromelain and fiber have also been extracted from pineapple plant. In China, most of the pineapples are sold in the home market [3]. Half of them come from Hainan province. Most of pineapples in Hainan province are sold to northeastern- and northwestern-China, Hongkong and Marco [3].

\section{Risks and Challenges in Pineapple Industry in China}

Although pineapple industry played important roles in economics of tropicaland subtropical-areas in China, some risks have appeared in recent years. These included sale, cultivar, processing, plant disease, and so on. These risks should be given attention, or the development of pineapple industry in China might be hindered.

\subsection{Pineapple Fruits Cannot Be Sold in Short Time in Harvest Season}

Most pineapples are harvested from March to May. They cannot be sold fully in such short time. However, pineapple fruit cannot be stored for long time. If they are not sold in two to three weeks, the fruits will be deteriorated. Furthermore, litchi is harvested in May and June. Partial market will be occupied by litchi. These cause the low price of pineapple. In some years, the income of some farmers can not compensate the planting cost. Some pineapple plantations were deserted. In some plantations, pineapple plants were discarded and other crops were grown.

\subsection{The Structure of Cultivars Is Single}

Although most pineapples sold in international market are selected from Smooth cayenne, the largest-grown variety of pineapple in China is "Comte de Paris" [4]. This cultivar was selected from Queen. The vegetation period of this cultivar was shorter. Exterior appearance was good. The color of fruit in maturity is golden yellow. Storing period is longer [5]. The plant of "Comte de Paris" is easy to induce inflorescence. Because of these traits, farmers are ready to plant "Comte de Paris" and dealers will buy the fruits of "Comte de Paris". However, 
"Comte de Paris" pineapple has deep fruitlets and thick peel. Its edible rate is less. To get more pulp, the eater need cut the fruit along the fruitlet. It is inconvenient to prepare for eating. There are much glucoside and bromelain in "Comte de Paris" fruit. Some consumers will have harsh feeling in mouth and tongue after eating. To alleviate this uncomfortable feeling, the cut fruit need to be soaked in sodium-chloride solution before eating. These characteristics make some people will not buy pineapple. This caused less-sale volume and lower price.

\subsection{The Processing Techniques Need to Be Improved}

Most pineapples in China were sold in fresh fruit. Only small part was processed into fruit tin, juice or other products. In the year when the price of fresh fruit was high, the company cannot buy enough fruits for processing. When the price of fresh fruit was low, the company cannot buy too many fruits. The volume of pineapple fruits for processing companies is instable. This made the processing company will not devote much capital for research and buying advanced facilities. In the year that many pineapple fruits cannot be sold, the processing companies cannot buy too many fruits either.

\subsection{Fruit Diseases Were to Be Controlled}

Black rot is an important disease for pineapple fruit. Sometimes, the disease rate can reach to $40 \%$ [5]. This disease was close related with wounds in fruit peel and high temperature. To improve the production, farmers always spray expansion agent before harvest. As the expansion agent can expanse fruit fast, many minute wounds also formed. Considering high temperature, pathogenic bacteria reproduce fast in the wounds. The fruits infected always rot completely in 2 to 3 days. When the dealers buy fruits, the fruits infected seemed good. But when they were transported to destination, many fruits rotted. Heavy loss might be brought to dealers. In the next year, the dealers will not buy pineapples in this area. This made the fruit price in such areas fall. Heavy loss will be brought to the farmers.

In recent years, water-heart fruits have also been found in market. The surface of water-heart fruits seemed same with that of normal fruits. However, if the fruit was cut, the pulp of water-heart fruit would be found like water. Water-hearts always happened in summer, when heavy rains often fall. Many farmers lost because of water-heart fruits.

\section{Work to Be Done for Resolving These Problems}

To resolve these problems, the following work might be done in the future.

1) New varieties for harvesting throughout the year should be selected

To raise the profit of the farmers, pineapple fruits should be avoided to sell in short period. Pineapple harvest period should be adjusted to the whole year. If pineapple fruits can only be sold during the short period, the price cannot be improved and the farmers' interests cannot be guaranteed. Using different varie- 
ties, in Hainan province, fresh pineapple fruits can be sold in market from December to the next June now. The most important variety is Tainong 13. Theoretically, the fresh fruits of Tainong 13 can be sold from August to the next February [5]. Its fruiting period is the longest among the varieties these days. In China, from December to the next February, most pineapples in market are Tainong 13. However, the weight of single fruit of Tainong 13 is only $1.2 \mathrm{~kg}$. The ratio of fiber to sugar acid is 58 [5]. It has no remarkable characteristics. The quality and consumers' evaluation are not prominent. New varieties for selling in the whole year are wanted. More attention should be paid to select new varieties with prominent characteristics whose harvesting time is throughout the year.

$\mathrm{New}$ varieties with high qualities should be introduced and popularized. Although "Comte de Paris" pineapple has many merits, its shortcomings are obvious. If consumers do not buy fruits of "Comte de Paris", the structure of varieties planted should be adjusted. Other varieties with higher ratio of sugar to acid, easier to eat, such as Tainong varieties and MD2, should be introduced and grown.

2) More work should be done to study the technology on forcing inflorescence

Theoretically, pineapple inflorescence can be induced at any time in the whole year. The pineapple fruit can also be got during any time in the year [6]. However, it was always found that the inflorescences of some pineapple plants cannot be induced [7]. Flowering failures lead to fruit quality and harvesting problems. One main reason that some farmers will not give up "Comte de Paris" pineapple is that it is easy to force the inflorescence of this variety. In China, in the period between July and September, typhoon always passes through pineapple-production areas and heavy rains fall. It is difficult to find pineapple fruits in market during this period. The price of pineapple during this period was often high. If the pineapple fruits can be harvested during this period, the interests of farmers will be high. However, to do this, the inflorescence should be forced from March to April. Pineapple plants justly flower naturally in February. It is difficult to force inflorescence from March to April. Furthermore, from July to September, rainfall in pineapple-production area in China is always heavy. Pineapple fruits in field are always watered and spotted, resulting in water-heart fruits. To harvest pineapple fruits from July September and get high interests, these problems should be resolved.

3) Precision fertilization for new varieties

Although some new varieties have excellent superiors in qualities and production, their characteristics in physiology are unknown to farmers. Furthermore, some new varieties have inherent diseases in physiology [5]. For example, seedlings of Tainong 16 are always languished. Fruits and stems of Tainong 17 are sometimes cracked [5]. If these problems are not resolved, some farmers will not cultivate these varieties. Lack of nutrient elements might lead to these problems. Studying the mechanisms underlying and precision fertilization are important for popularizing the new pineapple varieties.

4) Studying technologies for propagating plantlets fast and low cost 
Eminent plantlets are important in pineapple industry. Farmers and corporations always used suckers in parent plants for cultivation [8]. Sometimes, pathogenic bacteria are hidden in these suckers. Some diseases spread fast after the suckers were planted. Suckers' sizes also varied naturally, making flowering and fruit formation erratic [9]. Selecting tissue-culture seedlings can avoid these problems [10] [11] [12] [13] [14]. However, tissue-culture seedlings always have longer vegetation period than suckers. Furthermore, tissue-culture seedlings are much more expensive than suckers [15]. These inferiors caused farmers and corporations will not choose tissue-culture seedlings. How to decrease the cost and shorten the vegetation period of tissue-culture seedlings are important for persuading farmers choose them.

5) Prevention and control of disease in fruits before harvesting

Black rot and water heart are important diseases in pineapple fruits. If dealers found some fruits are black rot or water heart at one place, they will not purchase the pineapple fruits in this area in the next year. The reasons causing black rot are complicated. Unreasonable using expansion agent might be a main origin. Farmers often used expansion agent for increasing fruit weight. However, many minute wounds also formed with the fruit expanses fast. At high temperature, pathogenic bacteria enter the wounds and reproduce fast in the wounds. To prevent and control black rot, persuading farmers not spraying expansion agent before harvesting is important. Water heart was caused by heavy rain during fruit was developed. Drain the accumulating water in pineapple garden in time is important for preventing water-heart fruit.

\section{Conclusion}

The structure of varieties of pineapple in China is simple. The harvesting period is centralized. The price of pineapple fruits is often low. The processing techniques for pineapple are simple. These challenges hindered the further development of pineapple industry. In the future, new varieties with higher qualities and that can be harvested in a longer period should be selected. More work should be done in the technology on inducing inflorescence of new varieties. Precision fertilization for new varieties should be researched and developed. The technology for cultivating tissue-culture seedlings fast and at low cost should also be studied. The diseases in fruits should be prevented and controlled before harvesting.

\section{Acknowledgements}

This work was supported by Central Public-interest Scientific Institution Basal Research Fund for Chinese Academy of Tropical Agricultural Sciences (No. 1630092019005).

\section{Conflicts of Interest}

The authors declare no conflicts of interest regarding the publication of this paper. 


\section{References}

[1] Koia, J.H., Moyle, R.L. and Botella, J.R. (2012) Microarray Analysis of Gene Expression Profiles in Ripening Pineapple Fruits. BMC Plant Biology, 12, 240.

https://doi.org/10.1186/1471-2229-12-240

[2] Li, Y., Wu, Y., Wu, B., Zou, M., Zhang, Z. and Sun, G. (2011) Exogenous Gibberellic Acid Increases the Fruit Weight of "Comte de Paris" Pineapple by Enlarging Flesh Cells without Negative Effects on Fruit Quality. Acta Physiologiae Plantarum, 33, 1715-1722. https://doi.org/10.1007/s11738-010-0708-2

[3] Jin, Y. (2016) The Pineapple Industry of China Development Report and Situation Forecast in 2015. Information in Tropical Agriculture in World, 9, 16-24.

[4] Firoozabady, E., Heckert, M. and Gutterson, N. (2006) Transformation and Regeneration of Pineapple. Plant Cell, Tissue and Organ Culture, 84, 1-16. https://doi.org/10.1007/s11240-005-1371-y

[5] He, J.-H., Chen, H.-R., Huang, H.-J., Wang, J.-H. and Huang, H.-N. (2015) The New Varieties and High-Quality- and High-Production-Cultivation Technology of Pineapple (Ananas comosus L.). China Agricultural Science and Technology Press, Beijing.

[6] Min, I.X. and Bartholomew, D.P. (1996) Effect of Plant Growth Regulators on Ethylene Production, 1-Aminocyclopropane-1-Carboxylic Acid Oxidase Activity, and Initiation of Inflorescence Development of Pineapple. Journal of Plant Growth Regulation, 15, 121-128. https://doi.org/10.1007/BF00198926

[7] Turnbull, C.G.N., Sinclair, E.R., Anderson, K.L., Nissen, R.J., Shorter, A.J. and Lanham, T.E. (1999) Routes of Ethephon Uptake in Pineapple (Ananas comosus) and Reasons for Failure of Flower Induction. Journal of Plant Growth Regulation, 18, 145-152. https://doi.org/10.1007/PL00007062

[8] Firoozabady, E. and Gutterson, N. (2003) Cost-Effective in Vitro Propagation Methods for Pineapple. Plant Cell Reports, 21, 844-850.

[9] Sripaoraya S, Marchant R, Power JB, Davey MR. (2003)Pant Regeneration by Somatic Embryogenesis and Organogenesis in Commercial Pineapple (Ananas comosus L.). In Vitro Cellular \& Developmental Biology_Plant, 39, 450-454. https://doi.org/10.1079/IVP2003445

[10] Mathews, H.V. and Rangan, T.S. (1979) Multiple Plantlets in Lateral Bud and Leaf Explant in Vitro Cultures of Pineapple. Scientia Horticulturae, 11, 319-328. https://doi.org/10.1016/0304-4238(79)90016-5

[11] Zepeda, C. and Sagawa, Y. (1981) In Vitro Propagation of Pineapple. HortScience, $16,495$.

[12] Fitchet, M. (1990) Clonal Propagation of Queen and Smooth Cayenne Pineapple. Acta Horticulturae, 275, 261-266 https://doi.org/10.17660/ActaHortic.1990.275.31

[13] Fitchet-Purnell, M. (1993) Maximum Utilization of Pineapple Crowns for Micropropagation. Acta Horticulturae, 334, 325-330. https://doi.org/10.17660/ActaHortic.1993.334.33

[14] Kiss, E., Kiss, J., Gyulai, G. and Heszky, L.E. (1995) A Novel Method for Rapid Micropropagation of Pineapple. HortScience, 30, 127-129. https://doi.org/10.21273/HORTSCI.30.1.127

[15] Scherwinski-Pereira, J.E., Lima, E.C.A., Silva, T.L., Mesquita, A.G.G., Maciel, S.A. and Costa, F.H.S. (2012) Double-Phase Culture System for Large Scale Production of Pineapple. Plant Cell, Tissue and Organ Culture, 109, 263-269. https://doi.org/10.1007/s11240-011-0091-8 